\title{
Peningkatan Prestasi Belajar Agama Hindu SMP Melalui Model Pembelajaran Ekspositori
}

\section{Ni Made Sukardi*}

\section{A R T I C L E I N F O}

Article history:

Received 19 May 2018

Received in revised form 25 June 2018

Accepted 10 July 2018

Available online 25 August

2018

Kata Kunci:

Model Pembelajaran;

Ekspositori; Prestasi

Belajar; Agama Hindu

Keywords:

Learning Model;

Expository; Learning

Achievement; Hindu

Religion
A B S T R A K

Penelitian ini dilaksanakan di SMP Negeri 3 Sawan di Kelas VII A8 yang kemampuan siswanya untuk materi Agama Hindu rendah. Tujuan penulisan penelitian tindakan kelas ini adalah untuk mengetahui apakah model pembelajaran Expository dapat meningkatkan prestasi belajar siswa. Metode pengumpulan datanya adalah tes prestasi belajar. Metode analisis datanya adalah deskriptif kuantitatif. Hasil yang diperoleh dari penelitian ini adalah Expository dapat meningkatkan prestasi belajar siswa. Ini terbukti dari hasil yang diperoleh pada awalnya dengan nilai rata-rata 68,71, pada siklus I menjadi 6,49 dan pada siklus II menjadi 6,88. Kesimpulan yang diperoleh dari penelitian ini adalah model pembelajaran Expository dapat meningkatkan prestasi belajar.

\section{A B S T R A C T}

This research was carried out at SMP Negeri 3 Sawan in Class VII A8 whose students' ability to materialize Hinduism was low. The purpose of this class action research writing is to find out whether the Expository learning model can improve student learning achievement. The data collection method is a learning achievement test. The data analysis method is quantitative descriptive. The results obtained from this study are Expository can improve student learning achievement. This is evident from the results obtained initially with an average value of 68.71 , in the first cycle to 6.49 and in the second cycle to 6.88 . The conclusion derived from this study is that the Expository learning model can improve learning achievement.

\footnotetext{
* Corresponding author.

E-mail addresses: nisukardi@gmail.com
} 


\section{Pendahuluan}

Pendidikan merupakan proses perubahan sikap dan tingkah laku seseorang atau sekelompok orang dalam usaha mendewasakan manusia melalui upaya pengajaran dan latihan. Kegiatan pendidikan merupakan usaha yang dilakukan secara sengaja, penuh kesadaran, dan tanggung jawab.Membimbing anak didik agar memiliki watak dan kepribadian yang baik dan utuh. Pendidikan merupakan tanggung jawab bersama antar keluarga, masyarakat dan pemerintah.Pendidikan dalam rangka membina kaderkader pembangunan bangsa dilaksanakan secara terpadu melalui lembaga informal dalam keluarga, lembaga pendidikan formal di sekolah dan dalam pendidikan non formal di luar sekolah.

Dalam pelaksanan pendidikan, pada umumnya guru mempunyai peranan yang sangat penting dimana guru mentransfer pengetahuannya kepada siswa, sehingga siswa dapat menambah pengetahuan dan pengalaman. Dalam dunia pendidikan, khususnya pendidikan Agama Hindu diperlukan komitmen yang kuat karena pendidikan Agama menitik beratkan pada aspek afektif yaitu aspek yang terkait dengan sikap dan tingkah laku. Sikap dan tingkah laku merupakan dasar untuk memahami nilai-nilai agama, sehingga dapat tertanam dalam diri siswa serta menjadi pedoman hidup dari setiap langkah yang dilakukan. Peran mata pelajaran Agama Hindu adalah untuk pengembangan mental spiritual ,intelektual, sosial dan emosional siswa (Suyadnya, 2017).

Tujuan pendidikan nasional sebagaimana yang tertuang dalam Undang-Undang Nomor 20 Tahun 2003 tentang sistem pendidikan nasional adalah untuk berkembangnya potensi peserta didik agar menjadi manusia yang beriman dan bertakwa kepada Tuhan Yang Maha Esa, berakhlak mulia, sehat, berilmu, cakap, kreaktif, mandiri, dan menjadi warga Negara yang demokratis serta bertanggung jawab (Departemen Pendidikan Nasional, 2003)

Agar terwujudnya pembaharuan sistem pendidikan nasional sesuai dengan tujuan pendidikan nasional yang di harapkan dalam Undang-undang nomor 20 tahun 2003 tentang pendidikan nasional tersebut maka diperlukan adanya strategi tertentu. Strategi pembaharuan pendidikan nasional meliputi: 1) pelaksanaan pendidikan agama serta akhlak mulia, 2) pengembangan dan pelaksanaan kurikulum berbasis kompetensi, 3) proses pembelajaran yang mendidik dan dialogis, 4) evaluasi, akreditasi, dan serta sertifikasi pendidikan yang membudidayakan, 5) peningkatan keprofesionalan pendidikan dan tenaga pendidikan, 6) penyediaan sarana belajar yang mendidik, 7) pembiayaan pendidikan sesuai dengan prinsip pemerataan dan berkeadilan, 8) penyelenggaraan pendidikan yang terbuka dan merata, 9) pelaksanaan wajib belajar, 10) pelaksanaan otonomi manajemen pendidikan, 11) pemberdayaan peran masyarakat, 12) pusat pembudayaan dan pembangunan masyarakat, dan pelaksanaan pengawasan dalam system pendidikan nasional (Departemen Pendidikan Nasional, 2003). Dengan strategi tersebut diharapkan visi, misi dan tujuan pendidikan nasional dapat terwujud secara aktif dalam penyelenggaraan pendidikan.

Sesuai dengan strategi pendidikan nasional tersebut di atas, maka pada jenjang pendidikan formal (sekolah) pelaksanaan pendidikan agama merupakan salah satu materi pembelajaran yang masuk ke dalam kurikulum. Dalam fungsinya sebagai salah satu materi pembelajaran yang diharapkan banyak berperan dalam membina sikap mental para peserta didik, maka pendidikan agama menduduki tempat yang strategi dalam system pendidikan di Indonesia (Parmajaya, 2001) pendidikan agama yang dimaksud untuk membentuk peserta didik menjadi manusia yang beriman dan bertaqwa kepada Tuhan Yang Maha Esa serta berakhlak mulia (Departemen Pendidikan Nasional, 2003).

Secara umum, dari akibat berkembangnya ilmu pengetahuan dan teknologi, menuntut adanya kompetensi yang memadai di kalangan para pengelola dan para teknisi pendidikan, terlebih lagi para guru pendidikan agama Hindu. Dalam sistem pembelajaran yang diterapkan para pendidik dewasa ini sangat dituntut adanya sistem dan metode pembelajaran yang di sesuaikan dengan perkembangan ilmu pengetahuan dan teknologi.

Sejalan dengan perkembangan ilmu pengetahuan dan teknologi di era globalisasi ini, metode pembelajaran dan cara pengelola sistem pendidikan harus disesuaikan dengan kebutuhan adanya perubahan. Hal ini disebabkan pemahaman intelektual, cara belajar, motivasi, minat, serta lingkungan siswa sekarang telah banyak mengalami perkembangan dan perubahan. Oleh karena itu, secara kualitatif seorang guru pendidikan agama Hindu perlu mempersiapkan diri kearah profesionalisme yang memadai. Untuk dapat menjadi guru yang professional dibidangnya, maka seorang guru pendidikan agama Hindu dituntut memiliki kompetensi yang memadai, terutama dalam hal yang menentukan strategi pembelajaran serta metode pembelajaran pendidikan agama Hindu yang tepat. Berhasil tidaknya suatu proses pembelajaran ditentukan oleh metode pembelajaran yang digunakan oleh seorang guru. Seorang guru harus mengenal, mempelajari, dan mengusai berbagai metode pembelajaran agar dapat menciptakan proses pembelajaran yang berhasil guna dan berdaya guna. 
Rumusan tujuan pembelajaran yang dibuat oleh guru tidak selalu hanya satu tujuan, kadangkadang banyak atau mungkin bahkan beberapa tujuan.Untuk mencapai tujuan pembelajaran tersebut maka guru memerlukan metode pembelajaran yang diharapkan dapat tercapai dengan baik. Dalam mencapai tujuan pembelajaran, metode pembelajaran dipandang sebagai salah satu alat atau suatu cara yang harus digunakan oleh guru agar tujuan pembelajaran dapat tercapai (Roestiyah, 1991) oleh karena itulah sudah sewajarnya bahwa setiap metode pembelajaran hanya dapat digunakan di dalam situasi dan tujuan tetentu, kalau situasi dan tujuannya berubah, maka cara mengajar harus lain. Hal inilah yang menjadi alasan seorang guru harus mampu memilih dan menggunakan metode yang paling efektif untuk mencapai suatu tujuan pembelajaran.

Berdasarkan pengamatan peneliti bahwa, prestasi belajar khususnya mata pelajaran pendidikan agama Hindu siswa Kelas VII A8 SMP Negeri 3 Sawan dapat dikategorikan hasil rendah. Hal ini ditunjukan dengan nilai rata-rata pada bidang studi pendidikan agama Hindu pada semester II masih rendah. Karena pada dasarnya anak didik sudah dikondisikan sedemikian rupa dengan norma-norma agama sejak kecil baik dalam kehidupan keluarga maupun kehidupan bermasyarakat.

Rendahnya prestasi belajar siswa tersebut cenderung dipengaruhi oleh metode pembelajaran yang kurang tepat. Pengaruh metode pembelajaran yang kurang tepat dalam pembelajaran pendidikan agama Hindu akan menciptakan suatu rutinitas belajar yang sangat menjemukan bagi siswa dan juga guru. Hal ini akan mengakibatkan kurangnya minat dan perhatian siswa terhadap materi pelajaran. Kurangnya minat dan perhatian siswa terhadap materi pelajaran akan sangat mempengaruhi peningkatan prestasi belajar siswa.

Untuk dapat meningkatkan prestasi belajar pendidikan agama Hindu pada siswa Kelas VII A8 SMP Negeri 3 Sawan, perlu dirancang model pembelajaran agar siswa mampu meningkatkan pemahaman konsep, sehingga permasalahan yang dihadapi dapat diatasi. Maka Peneliti akan menggunakan Model Pembelajaran Expository, karena penerapan model pembelajaran ini memiliki kelebihan yaitu menyampaikan keterangan terlebih dahulu berupa definisi, prinsip dan konsep materi pelajaran. Model ini merupakan model pembelajaran konvensional yang dalam praktek pelaksanaannya selalu digabungkan dengan metode lain dalam memberikan contoh-contoh latihan pemecahan masalah sperti metode demonstrasi, tanya jawab dan penugasan. Startegi ekspositori adalah strategi pembelajaran yang memadukan metode ceramah, tanya jawab, dan peragaan demonstrasi (Atriyanto, 2014). Dengan dipadukannya berbagai metode tersebut dalam kegiatan pembelajaran diharapkan siswa dapat memahami materi ajar tersebut. Penggunaan model ekspositori merupakan model pembelajaran mengarah kepada tersampaikannya isi pelajaran kepada siswa secara langsung. Berdasarkan latar belakang tersebut, maka topik ini menjadi sangat urgen untuk dikaji dengan fokus kajian pada Penggunaan Model Pembelajaran Expository Sebagai Upaya Untuk Meningkatkan Prestasi Belajar Agama Hindu Siswa Kelas VII A8 Semester II SMP Negeri 3 Sawan Tahun Pelajaran 2017/2018.

Untuk meningkatkan prestasi belajar siswa dalam mata pelajaran pendidikan agama Hindu dapat dilakukan dengan penerapan model pembelajaran Expository. Dalam Model pembelajaran Expository ini mampu merangsang siswa untuk dapat bertanggung jawab terhadap pekerjaannya, menuntut persiapan yang sangat matang, menuntut kemampuan yang matang dalam presentasi, menutut semangat yang tinggi untuk mengikuti pelajaran agar dapat mempersiapkan tampilan yang diharapkan, menuntut sebab akibat dari pelaksanaan diskusi. Meskipun Model pembelajaran Expository tidak secara otomatis dapat menghasilkan pengajaran yang efektif, tetapi penggunaan Model pembelajaran Expository ini akan memberikan dampak yang besar terhadap siswa dalam hal berpendapat, berani tampil di depan kelas, mengingat pelajaran dengan catatan yang dimiliki siswa. Dengan menggunakan Model pembelajaran Expository ini maka akan dapat menuntut kemampuan siswa untuk giat mempelajari apa yang disampaikan guru, mampu menampilkan dirinya di depan siswa-siswa yang lain. Dipihak lain, untuk dapat menyelesaikan tuntutan tersebut, inovasi yang dilakukan guru akan sangat menentukan. Inovasi tersebut berupa tuntunan-tuntunan, motivasi-motivasi, interpretasi serta kemampuan implementasi yang tinggi.Cara inilah yang dapat digunakan sebagai dasar pemecahan masalah yang ada. Berdasarkan uraian tersebut maka dipandang perlu mengangkat topik ini menjadi sebuah judul penelitian yaitu Model Pembelajaran Expository Sebagai Upaya Untuk Meningkatkan Prestasi Belajar Agama Hindu Siswa Kelas VII A8 SMP Negeri 3 Sawan Pada Semester II Tahun Pelajaran 2017/2018.

\section{Metode}

Penelitian ini merupakan Penelitian Tindakan Kelas (PTK) atau Classroom Action Research. PTK memiliki peranan yang sangat penting dan strategis untuk meningkatkan mutu pelajaran melalui suatu tindakan bermakna dengan menggunakan sebuah model atau suatu pendekatan pembelajaran yang 
diperhitungkan dapat memecahkan masalah atau memperbaiki situasi dan kemudian secara cermat mengamati pelaksanaannya untuk mengukur tingkat keberhasilannya.

Penelitian ini dilaksanakan di SMP Negeri 3 Sawan pada tahun ajaran 2017/2018. Sekolah ini berlokasi di Desa Suwug, Kecamatan Sawan, Kabupaten Buleleng. Di sekolah ini peneliti menemukan masalah seperti yang tertuang didalam latar belakang masalah di atas. Dengan permasalahan tersebut, maka peneliti memilih tempat ini yaitu SMP Negeri 3 Sawan sebagai tempat untuk mengadakan penelitian. Untuk melancarkan penelitian, maka waktu penelitian ini dilaksanakan pada semester genap tahun pelajaran 2017/2018 dilaksanakan selama 4 (empat) bulan, yaitu dari bulan Januari Sampai dengan Bulan April 2018.

Subyek penelitian adalah siswa Kelas VII A8 SMP Negeri 3 Sawan yang berjumlah 28 orang siswa, yang terdiri dari 17 orang laki-laki dan 11 Perempuan. Berdasarkan rumusan masalah di atas penelitian ini berfokus keadaan kelas atau tindakan Kelas VII A8 SMP Negeri 3 Sawan, adapun yang menjadi obyek penelitian,peneliti ingin meningkatkan prestasi belajar Agama Hindu siswa Kelas VII A8 SMP Negeri 3 Sawan.

Penelitian ini adalah penelitian tindakan kelas. penelitian ini akan berlangsung melalui beberapa siklus sesuai dengan waktu dan hasil yang di capai atau diinginkan. Dengan demikian pada siklus ke-n target yang diinginkan sudah harus tercapai. Pada setiap siklus terdapat beberapa tahapan kegiatan. Menurut Ebbut, 1985 (dalam Mawa, 2008) disebutkan bahwa salah satu karakteristik penelitian tindakan kelas adalah adanya proses pelaksanaan penelitian sebagai ada informasi yang merupakan balikan dari apa yang telah dilakukan oleh si peneliti. Proses tersebut merupakan proses yang dinamis dimana ada empat tahap, yaitu: 1) perencanaan tindakan, 2) pelaksanaan tindakan, 3) observasi yang dilanjutkan dengan analisis dan evaluasi, dan 4) refleksi.

Metode yang dipergunakan untuk mengumpulkan data dalam penelitian ini adalah dengan teknik observasi atau pengamatan secara langsung untuk mengamati tindakan dengan menggunakan metode Expository. Selanjutnya pada tiap siklus dilaksanakan tes untuk mengetahui hasil belajar siswa. Metode analisis data yang digunakan dalam penelitian ini adalah: (1) reduksi data adalah proses penyederhanaan yang dilakukan melalui seleksi, pemfokusan, dan pengabstraksian data mentah menjadi informasi bermakna, (2) paparan data adalah proses penampilan data secara lebih sederhana dalam bentuk paparan naratif, representasi tabular termasuk dalam format matriks, grafis, dan sebagainya dan (3) penyimpulan adalah proses pengambilan intisari dari sajian data yang telah terorganisir tersebut dalam bentuk pernyataan kalimat dan atau formula yang singkat dan padat tetapi mengandung pengertian yang luas.

Dalam penelitian ini dikatakan berhasil apabila adanya peningkatan nilai siswa setiap siklusnya dari nilai KKM mata pelajaran Agama Hindu SMP Negeri 3 Sawan kelas VII A8 yang sudah ditentukan yaitu $\geq 70$ dan dianggap tuntas belajar jika secara klasikal $85 \%$ dari jumlah siswa memperoleh nilai sekurang-kurangnya 70 dan aktivitas belajar siswa dianggap tuntas apabila sudah mencapai $75 \%$ dari jumlah siswa (Depdiknas, 2008)

\section{Hasil dan pembahasan}

Subyek penelitian ini adalah siswa Kelas VII A8 SMP Negeri 3 Sawan, Kabupaten Buleleng pada semester II sebanyak 28 orang siswa yang terdiri dari 17 orang siswa laki-laki dan 11 orang siswa perempuan. Untuk mengetahui kondisi awal kelas sebelum dilaksanakan tindakan atau treatment digunakan beberapa metode untuk memperoleh data antara lain dengan menggunakan test

Test yang dimaksud dalam penelitian ini adalah "Pre-test" yang dilakasanakan sebelum pemberian tindakan tepatnya dilaksanakan pada hari Jumat 2 Pebuari 2018, tes yang digunakan adalah tes obyektif dalam bentuk pilihan ganda dan hasil yang diperoleh bahwa angka rata-rata 68,71, daya serap sebesar 68,71\%, dan, ketuntasan belajar sebanyak 35,71 \% sedangkan kreteria ketuntasan minimal (KKM) sebagai target dalam penelitian ini sebesar 70. Dalam tes ini 6 orang siswa memperoleh nilai di atas KKM, dan 22 orang siswa lainnya memperoleh nilai di bawah 70 atau dalam kategori belum tuntas belajar. Atas dasar di atas, dipandang perlu adanya perbaikan pelaksanaan proses pembelajaran yang menekankan pada perbaikan pendekatan dan perbaikan pada penggunaan metode pembelajaran yang dikemas dalam model pembelajaran yang inovatif yang dirancang dalam sistem siklus.

\section{Pelaksanaan Siklus I (Satu)}

Pelaksanaan penelitian tindakan kelas ini dilaksanakan dalam beberapa siklus, dalam waktu 4 (empat) bulan dimulai dari bulan Januari sampai dengan bulan Mei 2018 yaitu pada siswa Kelas VII A8 SMP Negeri 3 Sawan, Kecamatan Sawan, kabupaten Buleleng pada semester II tahun pelajaran 2017/2018 dengan subyek penelitian sebanyak 28 siswa yang dirancang dengan penggunaan model pembelajaran 
Expository dalam pembelajaran pendidikan Agama Hindu dengan target yang diinginkan Nilai Rata - rata siswa 70., Daya Serap 70\%, Ketuntasan Belajar 85\%

1. Perecanaan Tindakan

Peneliti menyusun perencanaan tindakan yang selanjutnya dilaksanakan pada Pendidikan Agama Hindu Kelas VII A8 SMP Negeri 3 Sawan dengan langkah-langkah sebagai berikut :

1) Mempersiapkan pokok bahasan yang akan diajarkan (silabus dan RPP terlampir).

2) Mempersiapkan kopetensi yang diharapkan pada siswa.

3) Membuat indikator keberhasilan.

4) Mempersiapkan alat pembelajaran, metode pembelajaran dan sumber pembelajaran yang digunakan.

5) Menyusun seperangkat tes hasil belajar.

Penelitian ini dilaksanakan dengan berkolaborasi dengan guru bidang studi Pendidikan Agama Hindu. Kepada guru yang bersangkutan peneliti telah menyampaikan maksud dan tujuan serta cara yang harus diterapkan dalam proses pembelajaran. Selanjutnya peneliti sebagai observer yang bertugas memantau kegiatan pembelajaran yang dilaksanakan oleh guru bidang studi Pendidikan Agama Hindu Kelas VII A8 SMP Negeri 3 Sawan,

2. Pelaksanaan Tindakan

Dalam kegiatan ini peneliti menyuruh guru untuk melaksanakan rencana pembelajaran yang telah disiapkan sebelumnya. Pelaksanaan tindakan dalam sistem siklus setiap siklusnya terdiri dari 4 kali tatap muka masing masing $1 \times 45$ menit dengan rincian sebagai berikut :

1) Pertemuan I (pertama) mengenai : Menghayati ajaran Kitab Suci Veda sebagai tuntunan hidup

2) Pertemuan II ( kedua) mengenai : Memahami Kitab Suci Veda sebagai tuntunan hidup

3) Pertemuan III ( ketiga) mengenai : Mengkodifikasi Kitab Suci Veda sebagai tuntunan hidup

4) Pertemuan IV (keempat) diadakan evaluasi dan post-test untuk mengukur atau mengetahui prestasi belajar siswa.

3. Evaluasi dan Analisis

Untuk mengetahui keberhasilan pelaksanaan pada siklus I, diperlukan adanya evaluasi terhadap proses pembelajaran yang telah dilaksanakan di mana post-test yang terdiri dari evaluasi proses yang dilaksanakan pada akhir siklus I tepatnya pada hari Jumat 2 Maret 2018. Evaluasi hasil yang digunakan tes hasil belajar, sedangkan untuk evaluasi proses digunakan metode observasi untuk tes hasil, tes yang digunakan post test dalam bentuk tes obyektif tipe pilihan ganda sebanyak 20 item dengan option sebanyak 4 option (a, b, c, dan d) dengan bobot masing-masing soal 1. Tes yang dibuat disesuaikan dengan materi pelajaran yang yang telah dijelaskan atau diajarkan. Pelaksanaan tes diatur sedemikian rupa dengan memperhatikan agar peserta tes dapat bekerja nyaman, tertib, tidak bekerja sama satu dengan yang lainnya. Waktu yang disediakan untuk mengerjakan tes selama 30 menit. Hasil yang diproleh dianalisis untuk mencari angka rata - rata atau rerata kelas, Daya serap dan Ketuntasan Belajar. Untuk lebih jelasnya tentang hasil Post-Test siklus I tersebut akan dikemukakan dalam Gambar 1.

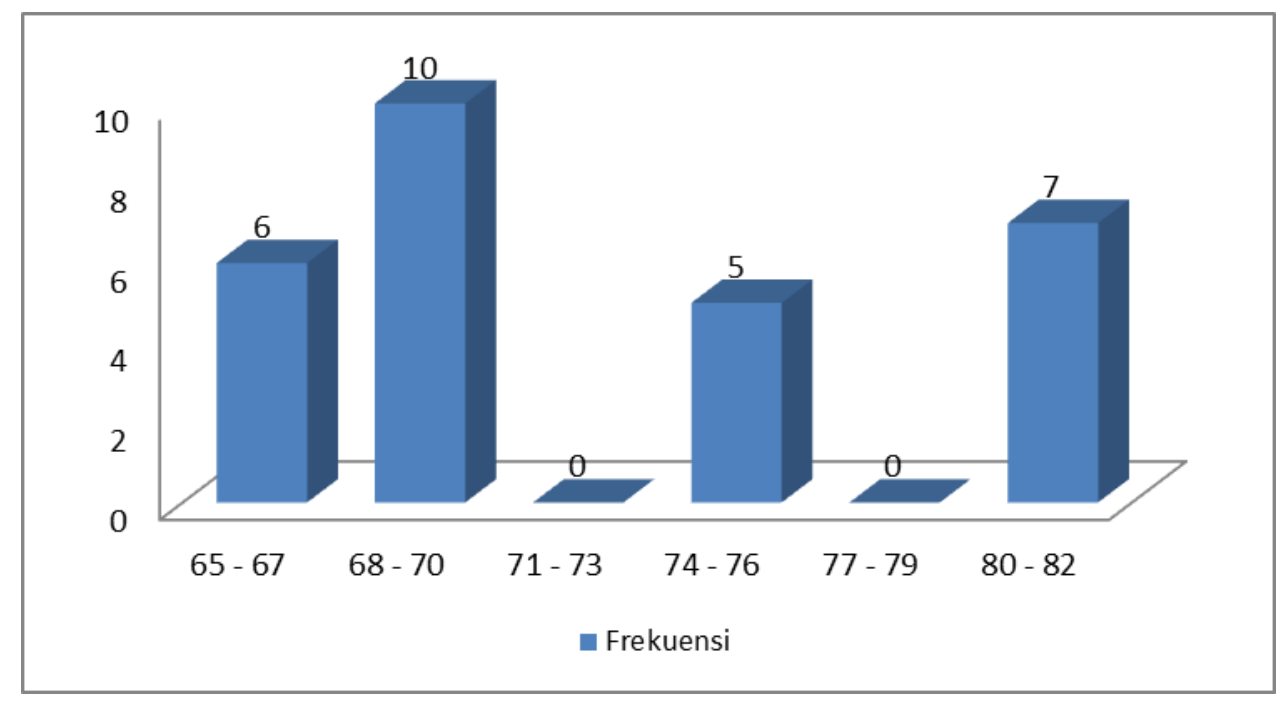

Gambar 1. Prestasi Belajar Agama Hindu Siswa Kelas VII A8 Semester II Tahun Pelajaran 2017/2018 Siklus I

Berdasarkan atas hasil prestasi belajar di atas, dan jika dibandingkan dengan target yang diinginkan yaitu tercapainya prestasi yang ditunjukan dengan nilai rata-rata 72,32 , daya serap $72,32 \%$ 
dan ketuntasan belajar 78,57\% maka hasil penelitian pada siklus I ini belum memenuhi target yang diharapkan. Oleh karena itu perlu adanya perbaikan pada siklus berikutnya yaitu siklus II.

4. Refleksi

Mengacu pada hasil penelitian di atas, baik dari proses pembelajaran maupun hasil atau prestasi belajar yang dicapai pada siklus I belum memenuhi target. Hal ini dapat dilihat dari data sebagai berikut prestasi belajar dimana rata-rata kelas sebesar 72,32 dengan daya serap 72,32\% serta ketuntasan belajar sebesar 78,57\% hal ini berarti masih dibawah target yang diinginkan yaitu rerata kelas 70, daya serap $70 \%$ dan ketuntasan belajar $85 \%$ berdasarkan data tersebut di atas, maka langkah perbaikan harus tetap dilakukan pada siklus II.

Berpijak dari hasil penelitian terhadap pelaksanaan tindakan pertama (1) ada beberapa hal yang dapat peneliti jadikan catatan, di awal pertemuan banyak siswa belum siap dalam mengikuti pelajaran. Hal itu terbukti dari ketidakmampuan siswa untuk menjawab latihan-latihan sesuai dengan pokok bahasan. Padahal tujuan dari hal tersebut adalah untuk membantu pemahaman siswa dalam hubungannya dengan penguasaan dan pemahaman materi yang terdapat dalam pokok bahasan dalam pembelajaran. Ketidaksiapan siswa lebih tampak lagi pada saat guru pengajar memberikan soal-soal pretest maupun post test untuk dikerjakan oleh siswa secara individual, banyak siswa kaget dan kebingungan untuk mencari jawaban baik dari buku maupun bertanya kepada temannya. Mengatasi hal ini, guru mencoba memberikan pengarahan tentang maksud dan tujuan diberikannya soal-soal pre-tes, maupun post tes namun itu semua tidak berpengaruh banyak terhadap proses pembelajaran.

Dalam penerapan model pembelajaran Expository, memang banyak memiliki kelebihan dan juga memiliki kelemahan. Adapun beberapa kelemahan yang dijumpai dalam tindakan siklus pertama ini yang harus disempurnakan dalam siklus kedua adalah sebagai berikut :

1) Masih banyak siswa yang ragu-ragu dalam memberikan tanggapan atau jawaban terhadap temannya.

2) Jawaban yang diberikan siswa masih sangat sederhana dan terkesan hapalan saja.

3) Masih ada beberapa siswa kurang mengembangkan kemampuannya secara optimal untuk menjawab semua latihan-latihan soal.

Untuk mengukur kelemahan itu digunakan instrumen pedoman observasi belajar-pembelajaran. Jika dilihat dari beberapa kelemahan di atas, maka dapat mempengaruhi hasil balajar, karena itu peneliti berkolaborasi dengan guru pengajar akan mengadakan suatu alternatif pemecahan dan perbaikan tindakan pada siklus pertama ini yang terlebih dahulu telah didiskusikan dengan siswa. Pertama, peneliti bersama guru pengajar memberikan motivasi kepada siswa agar memunculkan rasa percaya diri dan keberanian dalam setiap menjawab latihan-latihan soal. Kedua, peneliti bersama-sama dengan guru pengajar akan mengajak Siswa untuk mnjawab latihan-latihan, lebih banyak mengembangkan kemampuan afektif siswa, serta kembali menekankan konsep belajar yang mandiri serta aktif. Ketiga, guru pengajar akan berkeliling pada saat siswa mengerjakan latihan-latihan soal sehingga dapat memantau kegiatan siswa jika mengalami kesulitan. Terakhir, peneliti melalui guru pengajar memotivasi siswa agar tertantang untuk mencari literatur yang lain dalam mengembangkan kemampuannya menjawab latihanlatihan.

\section{Pelaksanaan Siklus Ke-2}

Pelaksanaan siklus II ini tidak berbeda jauh dengan siklus sebelumnya, yaitu siklus I, hanya saja ada beberapa hal yang perlu mendapat perhatian dan penekanan yang lebih khusus selama proses pembelajaran, pembelajaran diarahkan untuk tercapainya peningkatan prestasi belajar.

1. Perencanaan Tindakan

Pada prinsipnya perencanaan siklus I dengan siklus II adalah sama hanya saja ada penyempurnaan dalam penggunaan model pembelajaran dengan media dan sarana yang ada. Penanaman konsep masih perlu diulang, perlu di perjelas hubungan materi secara kontekstual, penggunaan media lebih dimantapkan serta pemberian motivasi belajar.

2. Pelaksanaan Tindakan

Pelaksanaan tindakan siklus kedua (II) ini bertujuan untuk mengadakan perbaikan-perbaikan terhadap kekurangan-kekurangan yang terdapat pada pelaksanaan tindakan siklus pertama (I) sehingga tercapai target yang diinginkan. Dalam pelaksanaan tindakan siklus kedua (II) ini, peneliti bersama-sama guru pengajar kembali merancang mekanisme pembelajaran yang tentunya didasarkan atas kekurangankekurangan dan kelebihan yang terdapat pada pelaksanaan tindakan siklus pertama (I).

Dalam kegiatan ini peneliti melaksanakan rencana pembelajaran yang telah disiapkan sebelumnya. Pelaksanaan tindakan dalam sistem siklus setiap siklusnya terdiri dari 4 kali tatap muka masing -masing $2 \times 45$ menit dengan rincian sebagai berikut:

1) Pertemuan I (pertama) mengenai : Mengurutkan bentuk-bentuk pelaksanaan Yajna

2) Pertemuan II (kedua) mengenai : Menguraikan syarat-syarat pelaksanaan Yajna 
3) Pertemuan III (ketiga) mengenai : Menyajikan Contoh Panca Yajna yang tergolong Tamasika, Rajasika dan Sattwika

4) Pertemuan IV (keempat) diadakan evaluasi dan post-test untuk mengukur atau mengetahui prestasi belajar siswa.

3. Evaluasi dan Analisis

Untuk mengetahui keberhasilan pelaksanaan pada siklus II, diperlukan adanya evaluasi terhadap proses pembelajaran yang telah dilaksanakan di namai post-test yang terdiri dari evaluasi proses yang dilaksanakan pada akhir siklus II tepatnya pada hari Kamis, 2 Oktober 2013. Evaluasi hasil yang digunakan tes hasil belajar, sedangkan untuk evaluasi proses digunakan metode observasi untuk tes hasil, tes yang digunakan sama dengan tes yang dipakai pada pre-test maupun Post- test pada siklus I yaitu hasil belajar dalam bentuk tes obyektif tipe pilihan ganda sebanyak 20 item dengan option sebanyak 4 option (a, b, c, dan d) dengan bobot masing-masing soal 1 . Tes yang dibuat disesuaikan dengan materi pelajaran yang telah dijelaskan atau diajarkan. Siswa dapat bekerja nyaman, tertib, tidak bekerja sama satu dengan yang lainnya. Waktu yang disediakan untuk mengerjakan tes selama 30 menit. Hasil yang diproleh dianalisis untuk mencari angka rata-rata atau rerata kelas, Daya serap dan Ketuntasan Belajar. Untuk lebih jelasnya tentang hasil Post-Test siklus II tersebut akan dikemukakan dalam Gambar 2.

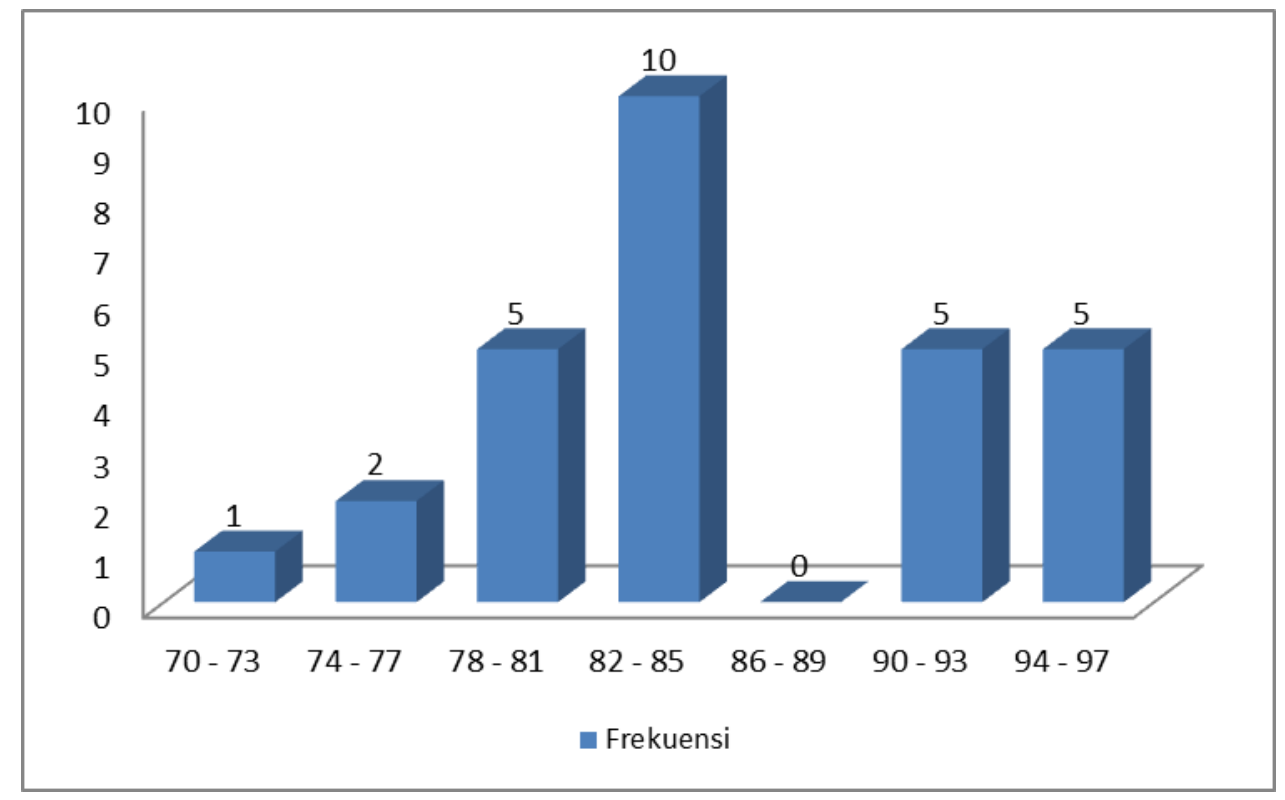

Gambar 2. Prestasi Belajar Agama Hindu Siswa Kelas VII A8 Semester II SMP Negeri 3 Sawan Tahun Pelajaran 2017/2018 Siklus II

Berdasarkan atas hasil prestasi belajar di atas, dan jika dibandingkan dengan target yang diinginkan yaitu tercapainya prestasi yang ditunjukan dengan nilai rata-rata 70 , daya serap $70 \%$ dan ketuntasan belajar $85 \%$ dan hasil penelitian pada siklus II ditunjukan dengan nilai rata-rata 85,54 , daya serap $85,54 \%$ dan ketuntasan belajar 100\% maka hasil penelitian pada siklus II sudah memenuhi target, bahkan melebihi dari target yang diinginkan sehingga penelitian ini dihentikan/ berakhir pada siklus II.

4. Refleksi

Mengacu pada hasil penelitian diatas, baik dari proses pembelajaran maupun hasil atau prestasi belajar yang dicapai pada siklus II sudah memenuhi target. Hal ini dapat dilihat dari data sebagai berikut prestasi belajar dimana rata-rata kelas sebesar 85,54 dengan daya serap 85,54\% serta ketuntasan belajar sebesar $100 \%$ hal ini berarti sudah memenuhi target bahkan sudah melebihi target yang diinginkan yaitu rerata kelas 70 , daya serap $70 \%$ dan ketuntasan belajar $85 \%$. Kenyataan ini menunjukan bahwa hasil penelitian telah melampaui target yang diinginkan. Hal ini disebabkan oleh : 1). Penerapan model pembelajaran Expository dapat dilaksanakan secara efektif, 2) suasana pembelajaran yang kondusif, 3) Pembelajaran berorientasi pada siswa dan, 4) adanya bimbingan belajar.

Hasil penelitian ini menunjukan bahwa penerapan model pembelajaran Expository dapat meningkatkan prestasi belajar Pendidikan agama Hindu pada siswa Kelas VII A8 Semester II SMP Negeri 3 Sawan. Hal ini ditunjukan dengan peningkatan prestasi belajar: pada siklus I rata-rata kelas (M) sebesar 72,32, Daya Serap (DS) sebesar 72,32\%, dan Ketuntasan Belajar (KB) 78,57\% dan mengalami 
peningkatan yang sangat signifikan pada sikus II yaitu rata-rata kelas (M) sebesar 85,54, Daya Serap (DS) sebesar 85,54\%, dan Ketuntasan Belajar (KB) 100\%.

Keberhasilan penelitian diatas dipengaruhi oleh terciptanya suatu proses pembelajaran yang kondusif, dimana siswa merasa senang dan gembira dalam mengikuti pelajaran, walaupun tugas serta latihan-latihan yang diberikan sangat melelahkan. Semua hal tersebut di atas disebabkan oleh karena penerapan model pembelajaran Expository sehingga dapat meningkatkan prestasi belajar siswa dalam pembelajaran Pendidikan Agama Hindu.

\section{Simpulan dan saran}

Pemicu rendahnya prestasi belajar ada pada faktor model pembelajaran yang digunakan guru dalam proses pembelajaran.Untuk itu penggunaan model pembelajaran yang sifatnya konstruktivis sangat diperlukan. Dalam hal ini peneliti menerapkan model pembelajaran Expository sebagai solusi untuk memecahkan permasalahan yang ada.

Dari hasil refleksi yang telah disampaikan di Bab IV dan dengan melihat semua data yang telah dipaparkan, dapat disampaikan bahwa pencapaian tujuan penelitian di atas dapat dibuktikan dengan argumentasi berikut. Pertama, dari data awal ada 18 siswa mendapat nilai di bawah KKM dan pada siklus I terjadi perubahan yaitu 6 siswa mendapat nilai di bawah KKM dan siklus II tidak ada siswa yang mendapat nilai di bawah KKM. Kedua, nilai rata-rata awal 68,71 naik menjadi 72,32 pada siklus I dan pada siklus II naik menjadi 85,54. Ketiga, dari data awal Prosentase siswa yang tuntas hanya 35,71\% sedangkan pada siklus mengalami peningkatan yaitu $78,57 \%$ dan pada siklus II meningkat secara signifikan yaitu $100 \%$.

Paparan di atas membuktikan bahwa model pembelajaran Expository dapat memberi jawaban sesuai tujuan penelitian ini. Semua ini dapat dicapai karena model pembelajaran Expository sangat efektif diterapkan dalam proses pembelajaran yang mengakibatkan siswa aktif, antusias dan dapat memahami materi yang diajarkan sehingga prestasi belajar siswa menjadi meningkat.

Berdasarkan hasil simpulan penelitian di atas, maka dapat diberikan saran, baik kepada pihak SMP Negeri 3 Sawan, bagi peneliti lain dan kepada para pengembang pendidikan. Kepada pihak-pihak yang terkait yang ikut terlibat langsung dengan proses penelitian di SMP Negeri 3 Sawan, diharapkan untuk mempertimbangkan proses pembelajaran bidang studi Pendidikan Agama Hindu dengan penerapan model pembelajaran Expository sebagai salah satu alternatif pembelajaran bidang studi Pendidikan Agama Hindu pada pokok bahasan yang lain. Bagi peneliti lain, walaupun penelitian ini sudah dapat membuktikan efek utama dari model pembelajaran Expository dalam meningkatkan prestasi belajar, sudah pasti dalam penelitian ini masih ada hal-hal yang belum sempurna dilakukan, oleh karenanya disarankan kepada peneliti lain yang berminat meneliti topik yang sama untuk meneliti bagian-bagian yang tidak sempat diteliti. Bagi pengembang pendidikan, selanjutnya untuk adanya penguatan-penguatan, diharapkan bagi peneliti lain untuk melakukan penelitian lanjutan guna memverifikasi data hasil penelitian ini

\section{Daftar Rujukan}

Agung, A. A. G. 1991. Pengantar Evaluasi. Singaraja: STKIP Agama Hindu.

Agung. A. A. G. 1998. Pengantar Evaluasi Pengajaran. Singaraja: IKIP Negeri Singaraja.

Arikunto, S. 2006. Penelitian Tindakan Kelas. Jakarta: Bumi Angkasa.

Atriyanto, Bayu, Edy Sulistiyo. 2014. "Pengaruh Strategi Pembelajaran Ekspositori Terhadap Hasil Belajar Siswa Pada Mata Diklat Memperbaiki Compact Cassete Recorder Kelas Xi Tav Di Sma Negeri 2 Surabaya". Jurnal Pendidikan Teknik Elektro, Volume 03, Nomor 02, hal. 09 - 13

Asri, B. 2005. Belajar dan Pembelajaran. Jakarta: Rineka Cipta.

Dirjen Pendidikan Dasar dan Menengah. 1984. Pedoman Proses Belajar Mengajar di Sekolah Dasar. Jakarta.

Depdikbud. 1986. Pedoman Penilaian Pendidikan Dasar. Jakarta

Dimyati dan Mudjiono. 1999. Belajar dan Pembelajaran. Jakarta : PT. Rineka Cipta. 
Djamarah, S. B. dan Aswan, Z. 2002. Strategi Belajar Mengajar. Jakarta : Rineka Cipta.

Hamalik, O. 1996. Metode Belajar dan Kesulitan Belajar. Bandung: Tarsito.

Nasution, F. 2001. Psikologi Pendidikan. Yogyakarta: CV. Rajawali.

Nasution, F. 2001. Hubungan Metode Mengajar, Keterampilan Belajar, Sarana Belajar dan Lingkungan Belajar dengan Prestasi Belajar Mahasiswa. Jurnal Ilmu Pendidikan.

Nasution. 2000. Berbagi Pendekatan Dalam Proses Belajar Mengajar. Bandung: Bumi Aksara.

Nurkancana, W. 1981. Evaluasi Pendidikan. Singaraja: Biro Penerbit FIF Unud.

Nurkancana, W. dan Sunartana. 1999. Strategi Belajar Mengajar. Jakarta: Depdikbud.

Safriadi. 2017. Prosedur Pelaksanaan Strategi Pembelajaran Ekspositori . Jurnal MUDARRISUNA Volume 7, Nomor 1,

Suanthara, I N. D. E. 2008. Rancangan Penelitian Tindakan Kelas (PTK). Unpublished. Singaraja: STKIP-AH.

Sukmawati, Dessy, Endang Purbaningrum. 2015. Pengaruh Model Pembelajaran Ekspositori Terhadap Kemampuan Berbicara Anak. Paud Teratai Vol 4, No 2

Suryabrata, S. 1987. Mengenal Metode Pengajaran Di Sekolah dan Pendekatan Baru Dalam Proses Belajar Mengajar. Yogyakarta: Amarta Buku.

Suyadnya, Ida Bagus Gede. 2017. Penerapan Model Pembelajaran Students Team Achievement Division (Stad) Dalam Meningkatkan Hasil Belajar Agama Hindu. Jurnal Penjaminan Mutu, Volume 3 Nomor 2.

Surya, M. 2004. Psikologi Pembelajaran dan Pengajaran. Bandung: Pustaka Bumi.

Tanu, Ketut. 2017.Mengembangkan Model Pembelajaran Agama Hindu Dalam Mewujudkan Peserta Didik Yang Religius. Prosiding Seminar Nasional Agama Dan Budaya (Semaya II).

Vigotsky. 1988. Belajar dan Pembelajaran. Jakarta: PT. Rineka Cipta.

Wardani. 2006. Strategi Belajar dan Pembelajaran. Jakarta: PT. Rineka Cipta. 